\title{
CAPACITATION OF HAMSTER SPERMATOZOA IN VITRO: THE RÔLE OF CUMULUS COMPONENTS
}

\author{
R. B. L. GWATKIN, O. F. ANDERSEN AND G. F. HUTCHINSON \\ Merck Institute for Therapeutic Research, Rahway, N.J., U.S.A. \\ (Received 20th Fuly 1971, accepted 28th Fuly 1971)
}

\begin{abstract}
Summary. The capacitating action of hamster oviduct contents collected shortly after ovulation was studied in vitro and found to be restricted to the cumulus oophorus. After dispersion of the cumulus with hyaluronidase, neither the cells nor the intracellular matrix material was active alone but only in combination. Spermatozoa became attached to the cells and later eluted, undergoing capacitation in the process. An essential component was removed from the cells by washing but was regenerated on reincubation for $8 \mathrm{hr}$. Treatment of the cells with neuraminidase blocked sperm attachment and capacitation. Frozen-thawed cells could replace viable cells. Cell concentrations had to exceed $10^{4} / \mathrm{ml}$ to produce a high level of capacitation. Cultured bovine follicle (granulosa) cells could replace hamster cumulus cells, but more than ten times the concentration was needed. The matrix component was dialysable, heat stable and at least partially inorganic. These experiments in vitro suggest that capacitation in the oviduct is produced by an intimate association between the cumulus cell and the spermatozoon. This association depends both on sialic acid residues located on the cell surface and on one or more low molecular weight substances provided by the matrix.
\end{abstract}

\section{INTRODUCTION}

Epididymal spermatozoa of the golden hamster are capacitated in vitro by material removed shortly after ovulation from the ampulla of the oviduct (Yanagimachi, 1969; Gwatkin \& Andersen, 1969). Such material comprises the oviduct fluid and the cumulus oophorus, the latter consisting of follicle cells embedded in a gelatinous matrix. Since such capacitation in vitro may constitute a model system for the process in vivo, we have investigated the way in which the individual components act. In this paper, we report studies on capacitation which demonstrate a key rôle for the cumulus cell in association with one or more low molecular weight components of the cumulus matrix.

\section{MATERIALS AND METHODS}

Female golden hamsters ( 5 to 7 weeks old) received an intraperitoneal injection of PMSG ( 25 i.u. PMSG, Ayerst 'Equinex') followed $52 \mathrm{hr}$ later by a similar injection of HGG ( 20 i.u. HGG, Ayerst 'A.P.L.'). Seventeen hours after the second 
injection, the animals were killed by quick stretching of the neck. Their oviducts were removed, placed under mineral oil (previously equilibrated with Krebs-Ringer solution) and a cut was made in the ampulla. The contents of five to ten oviducts, including eggs in cumulus which had escaped into the oil, were picked up in a micropipette and transferred to a 1-ml centrifuge tube. Oviduct fluid was separated by centrifugation at $500 \mathrm{~g}$ for $5 \mathrm{~min}$. The pellet (cumulus) was dispersed by a 5-min exposure to hyaluronidase (450 U.S.P. units/ml Dulbecco's phosphate-buffered saline). Each cumulus mass was dispersed with $40 \mu \mathrm{l}$ enzyme solution. The dispersed cells were obtained by centrifuging at $500 \mathrm{~g}$ for $5 \mathrm{~min}$ and the dissolved matrix (supernatant) was decanted. The cumulus cells were then washed three times in Medium 199M.

Capacitating activity was examined by the addition of an equal volume of epididymal sperm suspension $\left(10^{7}\right.$ motile spermatozoa $\left./ \mathrm{ml}\right)$, collected as described previously (Gwatkin \& Williams, 1970). After incubation at $37^{\circ} \mathrm{C}$ on a rocker (five to six oscillations/min) for $6 \mathrm{hr}$, groups of twenty cumulus-free ova (21 to $23 \mathrm{hr}$ after HCG) were added to each drop. After incubation for another $90 \mathrm{~min}$, the eggs were transferred to a slide, compressed slightly beneath a vaseline-edged cover glass and examined with a phase-contrast microscope for passage of sperm heads through the zona pellucida and sperm penetration into the vitellus.

Bovine follicle cells were cultured as described previously (Cirillo, Andersen, Ham \& Gwatkin, 1969). After 4 days, they were harvested with a rubberpoliceman and suspended in Medium 199M. The human lymphocyte cell line PGLG-33H (Glade, Kasel, Moses, Whang-Peng, Hoffman, Kammermeyer \& Chessin, 1968) was grown in Eagle's minimum essential medium supplemented with fetal calf serum $(20 \%)$. Guinea-pig lymphocytes were obtained by teasing the inguinal, popliteal and axillary lymph nodes in tissue culture medium, following enlargement of the nodes by an injection 1 week earlier with ovalbumin in complete Freund's adjuvant. Cells were suspended in 199M for testing. Suspensions of L cells were grown in Eagle's minimum essential medium supplemented with fetal calf serum $(10 \%)$.

Trypsin (bovine pancreatic crystalline, 196 units $/ \mathrm{mg}$ ), $\beta$-galactosidase $(E$. coli, chromat. purified, 82 units $/ \mathrm{ml}$ ) and neuraminidase (Clostridium perfringens, purified, 0.7 units $/ \mathrm{mg}$ ) were obtained from the Worthington Biochemical Corporation, Freehold, N.J. Hyaluronidase (bovine testicular, 465 U.S.P. units/mg) and insolubilized pronase (Enzite-Pro) were obtained from the Calbiochem Co. and Miles-Seravac, Ltd, respectively.

Freezing and thawing of cumulus cells was carried out in the vapour phase of a liquid-nitrogen freezer.

\section{RESULTS}

Table 1 shows that all of the capacitating activity of the oviduct contents $(17 \mathrm{hr}$ after HCG) resides in the cumulus mass. Neither the washed cumulus cells nor the matrix (solubilized with hyaluronidase) was active alone but when combined, they had essentially the same activity as the whole cumulus. With or without solubilized matrix, spermatozoa became attached to the cumulus cells 
within the first hour of incubation, causing the cells to clump (P1. 1, Fig. B). However, examination at the end of the 6-hr incubation revealed that a large proportion of the spermatozoa were detached and the cells were relatively dispersed (Pl. 1, Fig. C). Thus, capacitation in vitro involved an intimate association of spermatozoa with cumulus cells followed by dissociation. Matrix material was needed for this process to result in capacitation of the spermatozoa.

TABLe 1

CAPAGITATION OF HAMPSTER SPERMATOZOA BY COMPONENTS OF THE OVIDUGT LUMEN

\begin{tabular}{|c|c|c|}
\hline $\begin{array}{l}\text { Sperm. treated } \\
\text { for } 6 \text { hr with: }\end{array}$ & $\begin{array}{l}\text { Relative no. of sperm. } \\
\text { attached to cells after: } \\
\quad 1 \mathrm{hr} \quad 6 \mathrm{hr}\end{array}$ & $\begin{array}{c}\% \text { Ova } \\
\text { penetrated by } \\
\text { treated sperm.* }\end{array}$ \\
\hline $\begin{array}{l}\text { Oviduct contents } \\
\text { (17 hr after HCG) } \\
\text { Oviduct contents } \\
\text { without cumulus mass } \\
\text { Washed cumulus cells } \\
\text { Solubilized matrix } \\
\text { Washed cumulus cells + } \\
\text { solubilized matrix }\end{array}$ & $\begin{array}{l}++t \\
\overline{+}+ \\
\underline{+}++\end{array}$ & $\begin{array}{r}95 \\
0 \\
0 \\
0 \\
\\
80\end{array}$ \\
\hline
\end{tabular}

* Based on twenty ova.

TABLE 2

GAPACITATION OF HAMSTER SPERMATOZOA BY VARIOUS TYPES OF GELLS

\begin{tabular}{l|c|cc|c}
\hline $\begin{array}{c}\text { Type of cell used } \\
\text { to treat sperm. }\end{array}$ & Cells/ml & \multicolumn{2}{|c|}{$\begin{array}{c}\text { Relative no. of } \\
\text { sperm. attached to } \\
\text { cells after: } \\
1 \mathrm{hr}\end{array}$} & $\begin{array}{c}\text { \% } \mathrm{hr} \\
\text { peretrated by } \\
\text { treated sperm. }\end{array}$ \\
\hline Hamster cumulus & $2 \times 10^{3}$ & +++ & + & 0 \\
& $6 \times 10^{4}$ & +++ & + & 5 \\
& $3 \times 10^{5}$ & +++ & + & 65 \\
Bovine granulosa & $10^{6}$ & +++ & + & 75 \\
Guinea-pig lymphocytes & $3 \times 10^{5}$ & +++ & +++ & 90 \\
Human lymphocyte & $10^{6}$ & +++ & ++ & 50 \\
$\quad$ line (PGLC-33H) & $3 \times 10^{5}$ to $10^{4}$ & +++ & +++ & 0 \\
L Cells & $10^{6}$ to $10^{4}$ & +++ & +++ & 0 \\
\hline
\end{tabular}

\section{The cell component}

Table 2 shows that the concentration of cumulus cells had to exceed $10^{4} / \mathrm{ml}$ to produce a high level of capacitation, as judged by the percentage of eggs penetrated in $90 \mathrm{~min}$. Cultured bovine follicle (granulosa) cells could replace hamster cumulus cells, but more than ten times the cell concentration was needed. Guinea-pig lymphocytes, a human lymphocyte line and mouse L cells were ineffective. Thus, considerable, though not complete, cell specificity was 
involved. Effectiveness in capacitation appeared to be related to elution of spermatozoa from the cells after $6 \mathrm{hr}$ of incubation (Table 2).

The effect of enzymes on the capacitating ability of hamster cumulus cells is shown in Table 3 . Exposure to bacterial neuraminidase for 30 min completely prevented sperm attachment. There was little or no cell clumping (Pl. 1, Fig.

TABLE 3

EFFECT OF ENZYMES ON CAPACITATING ACTION OF HAMSTER CUMULUS GELLS

\begin{tabular}{|c|c|c|c|c|c|}
\hline Enzyme & $\begin{array}{c}\text { Exposure } \\
\text { time } \\
(\text { min })\end{array}$ & $\begin{array}{c}\text { Sperm } \\
\text { attachment }\end{array}$ & $\begin{array}{c}\text { Cell } \\
\text { clumping }\end{array}$ & $\begin{array}{l}\% \text { Ov } \\
\text { penetrated by } \\
\text { Exp. } 1\end{array}$ & $\begin{array}{l}a \\
\text { sperm. } \\
\text { Exp. } 2\end{array}$ \\
\hline None & 60 & + & + & 100 & 80 \\
\hline $\begin{array}{l}\text { Trypsin } \\
\text { (700 units/ml) }\end{array}$ & $\begin{array}{l}30 \\
60\end{array}$ & $\begin{array}{l}+ \\
+\end{array}$ & $\begin{array}{l}+ \\
+\end{array}$ & $\begin{array}{r}100 \\
40\end{array}$ & $\begin{array}{l}65 \\
42\end{array}$ \\
\hline $\begin{array}{l}\beta \text {-Galactosidase } \\
(82 \text { units } / \mathrm{ml})\end{array}$ & $\begin{array}{l}30 \\
60\end{array}$ & $\begin{array}{l}+ \\
+\end{array}$ & + & $\begin{array}{l}60 \\
40\end{array}$ & $\begin{array}{l}45 \\
20\end{array}$ \\
\hline $\begin{array}{l}\text { Neuraminidase* } \\
(0.7 \text { units } / \mathrm{ml})\end{array}$ & 30 & - & - & 0 & 0 \\
\hline
\end{tabular}

* Neuraminidase-treatment produced cell fragility which resulted in the loss of some cells during washing. Loss was restored before testing.

\section{TABLE 4}

EFFECT OF FREEZE-THAW ON CAPACITATING ACTION OF HYALURONIDASE-DISPERSED CUMULUS ON HAMSTER SPERMATOZOA

\begin{tabular}{l|c|c}
\hline \multicolumn{1}{c|}{ System used to treat sperm. } & $\begin{array}{c}\text { Incubation } \\
\text { time (hr } \\
\text { before freezing) }\end{array}$ & $\begin{array}{c}\% \text { Ova } \\
\text { penetrated by } \\
\text { treated sperm. }\end{array}$ \\
\hline $\begin{array}{l}\text { Dispersed cumulus } \\
\text { Dispersed cumulus, }\end{array}$ & 0 & 75 \\
but cell fragments removed & 0 & 0 \\
by centrifugation & Not frozen \\
Washed cells+supernatant (in PBS) & 0 & 75 \\
& 0 & 0 \\
Washed cells +supernatant + & 2 & 0 \\
equal vols 199M and 2\% FCS & 4 & 0 \\
& 8 & 0 \\
& 20 & 50 \\
\end{tabular}

PBS, phosphate buffered saline; FCS, fetal calf serum.

D) and no capacitation. Treatment with trypsin and $\beta$-galactosidase had no detectable effect on sperm attachment or on sperm-induced cell clumping, but the effectiveness of the cells for capacitation was significantly decreased.

Viability of the cumulus cell was not necessary for capacitation, since cumulus dispersed in hyaluronidase solution was still active after repeated freezing 

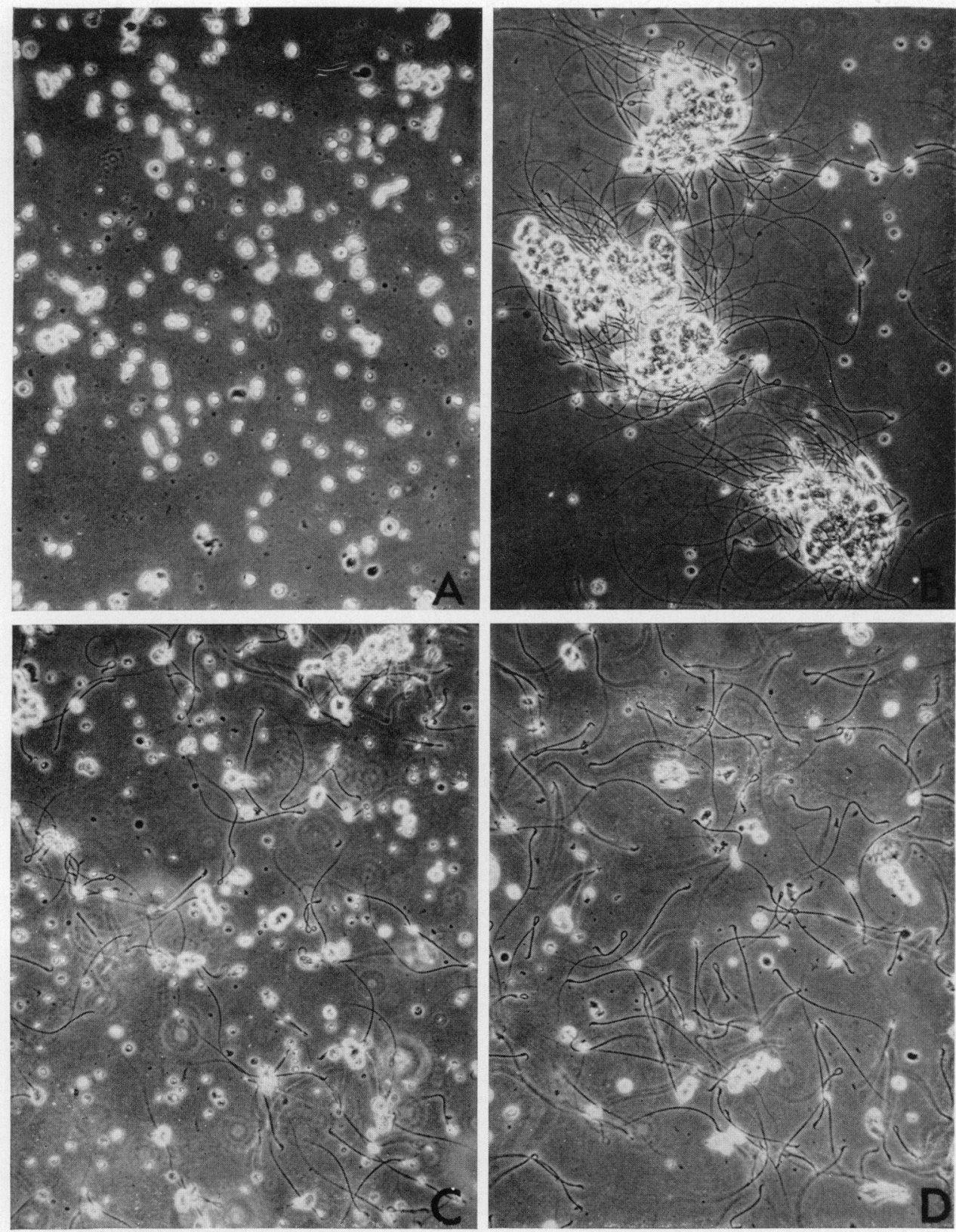

Interatetion of spermatorom with rumulue colls

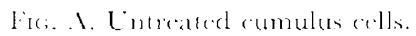

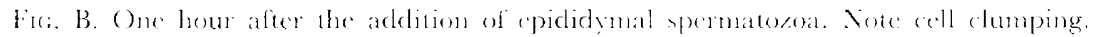

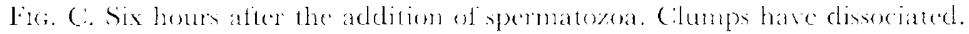

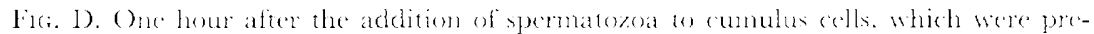

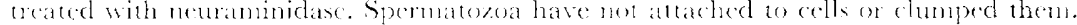


and thawing (see Table 4). The essential components were the cell fragments. Their removal by centrifugation ( $500 \mathrm{~g}$ for $5 \mathrm{~min}$ ) abolished capacitating action. In contrast to this behaviour of whole cumulus suspensions, when washed cumulus cells were combined with solubilized matrix and frozen, the mixture failed to produce capacitation unless the washed cells were incubated in tissue culture medium for about $8 \mathrm{hr}$ (Table 4). During this incubation, the cumulus cells regenerated material lost during the washing procedure.

\section{The matrix component}

Table 5 summarizes studies on the solubilized matrix component. Activity, lost on dilution to $1: 4$, was dialysable, stable to pronase and heat and was not

\section{TABLE 5}

EFFECT OF VARIOUS TREATMENTS OF THE SOLUBILIZED CUMULUS MATRIX ON THE CAPACITATION OF HAMSTER SPERMATOZOA

\begin{tabular}{l|c}
\hline \multicolumn{1}{c|}{$\begin{array}{c}\text { Treatment of } \\
\text { solubilized matrix }\end{array}$} & $\begin{array}{c}\text { \% Ova penetrated by sperm. } \\
\text { previously incubated with treated } \\
\text { supernatant }+ \text { washed cumulus cells }\end{array}$ \\
\hline Untreated & 60 \\
Diluted $1: 2$ & 45 \\
$1: 4$ & 0 \\
$1: 8$ & 0 \\
Dialysate (equal vol. 199M) & 40 \\
$5^{\circ} \mathrm{C}$ for $24 \mathrm{hr}$ & 50 \\
$60^{\circ} \mathrm{C}$ for $1 \mathrm{hr}$ & 48 \\
$100^{\circ} \mathrm{C}$ for $5 \mathrm{~min}$ & 55 \\
Ether-extracted & 55 \\
Ether extract & 0 \\
pH 2 for $2 \mathrm{hr}$ & 30 \\
pH 10 for $2 \mathrm{hr}$ & 30 \\
Pronase (insol. $1 \mathrm{mg} / \mathrm{ml}$ ) & 60 \\
Ashed (650 $\mathrm{C}$ for $7 \mathrm{hr}$ ) & 15 \\
\hline
\end{tabular}

extracted by ether. There appeared to be some loss in activity on exposure to $\mathrm{pH} 2$ or $\mathrm{pH} 10$ for $2 \mathrm{hr}$. On removal of organic substances by dehydration at $100^{\circ} \mathrm{C}$ followed by heating in a muffle-furnace to $650^{\circ} \mathrm{C}$ for $7 \mathrm{hr}$, the resultant white ash, made up to original volume in distilled water, repeatedly had about $25 \%$ of the activity of the original solubilized matrix. This shows clearly that at least a part of the activity of the matrix resides in its inorganic moiety.

\section{DISCUSSION}

The primary site of capacitation within the female genital tract of mammals has not been defined. However, Zamboni (1972) has reported that the uterotubal junction in the mouse closes a few minutes after mating. This suggests that it is the oviduct rather than the uterus which is involved in capacitating those spermatozoa destined to fertilize the egg. The experiments reported here show that such oviduct-mediated capacitation is dependent entirely on the cumulus. 
Other oviduct contents are not involved. Both components of the cumulus, the cells and the matrix, are critical. The spermatozoa enter an intimate association with the cumulus cell and in the presence of one or more heat stable, low molecular weight substances provided by the intracellular matrix, sperm capacitation is produced. In our system, the cumulus was separated with hyaluronidase in vitro into cells and solubilized matrix so that their individual rôles could be determined. However, in the female hamster, the cumulus mass remains intact, to be penetrated only by the relatively small number of spermatozoa which enter the oviduct.

Hamster cumulus cells were found to be relatively more effective for capacitating spermatozoa than the closely related granulosa cells of the bovine follicle. However, the latter were cultured for several days in vitro and we do not know how this may have affected their properties. Other cells that were tested were ineffective. Although the cumulus cell appears to be well adapted for its capacitating function, more extensive studies with other cells and cells grown under various conditions in vitro are needed to establish the extent of this specificity. It may not be restricted entirely to cells of follicular origin, since Ericsson (1969) has reported that rabbit spermatozoa become capacitated when mixed with mule eosinophils.

Since exposure of cumulus cells to neuraminidase prevented sperm attachment, this union appears to involve sialic acid residues. Sperm attachment was unaffected by washing the cumulus cells, but some other essential cell-surface component was removed, since cells frozen-thawed immediately after washing were inactive. The nature of this factor, which is regenerated after $8 \mathrm{hr}$ in vitro, remains to be identified.

\section{REFERENCES}

Cirillo, V. J., Andersen, O. F., Ham, E. A. \& Gwatkin, R. B. L. (1969) The effect of luteinizing hormone and adenosine $3^{\prime}, 5^{\prime}$-monophosphate on progesterone biosynthesis by bovine granulosa cells in culture. Expl Cell Res. 57, 139.

ERICsson, R.J. (1969) Capacitation in vitro of rabbit sperm with mule eosinophils. Nature, Lond. 221, 568.

Glade, P. R., Kasel, J. A., Moses, H. L., Whang-Peng, J., Hoffman, P. F., Kammermeyer, J. K. \& Chessin, L. N. (1968) Infectious mononucleosis: continuous suspension culture of peripheral blood leucocytes. Nature, Lond. 217, 564 .

GWATkin, R. B. L. \& ANDERSEN, O. F. (1969) Capacitation of hamster spermatozoa by bovine follicular fluid. Nature, Lond. 224, 1111.

Gwatkin, R. B. L. \& Williams, D. T. (1970) Inhibition of sperm capacitation in vitro by contraceptive steroids. Nature, Lond. 227, 182.

YANAGIMACHI, R. (1969) In vitro capacitation of hamster spermatozoa by follicular fluid. $\mathcal{f}$. Reprod. Fert. 18, 275.

Zambonı, L. (1972) Fertilization in the mouse. In: Biology of Mammalian Fertilization and Implantation, Chap. 8. Eds K. S. Moghissi and E. S. E. Hafez. G. G. Thomas, Springfield, Illinois, U.S.A. 